\title{
STANDARDISED ILEAL AMINO ACID DIGESTIBILITY OF SELECTED FEEDSTUFFS IN BROILER CHICKEN
}

\author{
U. O. Olayemi; A. F. Agboola*; and E. A. Iyayi \\ Dep. of Anim.1 Sci., Uni.y of Ibadan, Ibadan, Nigeria
}

Correspondence author: A. F. Agboola email: adebisi.agboola@gmail.com,

Received: 02/09/2020 Accepted: 24 /09/2020

\begin{abstract}
Standardised Ileal Amino Acid Digestibility (SIAAD) of maize, wheat, soybean meal (SM), groundnut cake (GC) and rice bran (RB) in broiler finisher diets was investigated. Three hundred and sixty 35-day old Arbor Acre broiler chicks were randomly allotted to a Nitrogen-Free Diet (NFD) and five semi-purified diets containing each of the test feedstuffs (maize, wheat, SM, GC and RB) as the sole source of protein. Diets were fed to ten birds of six replicates up to day-42 in a randomised complete block design. Chromic oxide $(5 \mathrm{~g} / \mathrm{kg})$ was added to the feed as an indigestible dietary marker. Six birds per replicate were asphyxiated with $\mathrm{CO}_{2}$ and digesta samples were collected from terminal ileum on day 42. The endogenous amino acid losses (EAAL), apparent ileal amino acid digestibility (AIAAD) and SIAAD were estimated. Highest EAAL concentration was found in threonine $(0.29 \mathrm{~g} / \mathrm{kg})$, while glutamic acid and alanine $(0.03 \mathrm{~g} / \mathrm{kg})$ had the least. Total AIAAD were 69.47, 59.49, 70.48, 73.04 and $62.21 \%$, in maize, wheat, SM, GC and RB, respectively. Correspondingly, total SIAAD were 70.86, 61.30, 71.76, 75.13 and $64.05 \%$. Least SIAAD values of amino acids were recorded in wheat compared to the other feedstuffs. Isoleucine had the highest increase in wheat and GC with 3.1 and 3.73\%, respectively. In SM and maize, threonine had the lowest increase with 8.0 and $0.94 \%$, respectively. Average increase of SIAAD over AIAAD for indispensable amino acid was 1.58, 1.95, 1.37, 2.24 and $2.10 \%$ for maize, wheat, SM, GC and RB respectively. Results from the present study showed that correcting AIAAD for endogenous losses using nitrogen-free method resulted in increased digestibility values for all the feedstuffs.
\end{abstract}

Keywords: Poultry feedstuffs, Dietary amino acid, Endogenous nitrogen losses, Broiler finisher diets 


\section{U. O. Olayemi et al.}

\section{INTRODUCTION}

Formulation of poultry diets based on total amino acids (AAs) has numerous negative implications such as high feed cost and excess nitrogen excretion which has a negative impact on the environment. Thus, knowledge of digestibility coefficients for individual AAs in raw materials and the requirement of digestible amino acids for a defined production target can enable formulation of diets closer to the requirements of the animals. According to Rostagno et al. (1995), diets formulated based on digestible AAs may encourage the use of more feedstuffs with low protein. This will improve the precision of least cost diets and reduce nitrogen output from poultry operations. The numerous debate among nutritionists on the relative merits of standardised and true digestible AA systems has been reported (Lemme et al., 2004; Adedokun et al., 2008) but there is no doubt that all digestible AA systems are superior to the use of total AAs in feed formulation. On this note, several methods have been employed for amino acid digestibility assay such as the analysis of AA in ileal content and excreta. However, apparent amino acid digestibility values from ileal digesta or excreta do not distinguish between AAs of dietary or endogenous origins. According to Fan et al. (1994), apparent amino acid digestibility (AAAD) values are influenced by level of feed intake and dietary protein concentrations. However, when AAAD values are not corrected for endogenous amino acid flow, it thus, underestimates amino acid digestibility values. Conversely, standardised ileal amino acid digestibility (SIAAD) assay gives accurate estimate of digestibility values as it represents apparent amino acid digestibility values corrected for endogenous amino acid losses (EAAL). However, information on SIAAD of commonly used feedstuffs is not adequately documented thus the need to augment the existing database of SIAAD for some selected feedstuffs. Therefore, SIAAD of five feedstuffs in broiler finisher diets were investigated.

\section{MATERIALS AND METHODS}

Three hundred and sixty (360) broiler chicks were randomly distributed (blocked by weight) into six dietary treatments with six replicates of ten birds each in a randomised complete block design. Five diets were formulated to contain maize, wheat, soybean meal (SM), groundnut cake (GC) and rice bran (RB) as the sole source of AA while a nitrogen-free diet was used to estimate basal endogenous amino acid losses (EAAL) from the birds. First 21 days, the birds were placed on a commercial broiler starter diets (non-test diets). On day 22, birds were placed on a commercial broiler finisher diet for a further 14 days. On day 35, the experimental diets were introduced and birds had free access to feed and water up to day 42. Chromium oxide was added to the feed as an indigestible dietary marker at $5 \mathrm{~g} / \mathrm{kg}$ of feed. On day 42 , six birds from each pen were selected, weighed and slaughtered. The digestive tract was carefully excised and the terminal two thirds of the section between Meckel diverticulum and $2 \mathrm{~cm}$ anterior to the ileo-caeco-colonic junction were severed and ileal digesta contents were gently flushed out with distilled water into containers on replicates basis, frozen at $-20^{\circ} \mathrm{C}$ and freeze-dried. The freeze dried samples were milled and stored for chemical analysis.

\section{Digestibility Calculations}

The ileal endogenous AA flow in $\mathrm{g} / \mathrm{kg} \mathrm{DM}$ intake from birds fed the NFD was calculated as:

AA in ileal digesta $(\mathrm{g} / \mathrm{kg}) \mathrm{x}$ diet chromium $(\mathrm{g} / \mathrm{kg}) /$ ileal digesta chromium $(\mathrm{g} / \mathrm{kg})$

Apparent ileal AA digestibility (AIAAD) (\%) $=\{1-($ diet chromium $(\mathrm{mg} / \mathrm{kg}) /$ ileal digesta chromium $(\mathrm{mg} / \mathrm{kg}) \quad \mathrm{x}$ (ileal digesta AA $(\mathrm{mg} / \mathrm{kg}) /$ diet AA $(\mathrm{mg} / \mathrm{kg})\} \times 100$ 
Standardised ileal AA digestibility (SIAAD) \% $=$ AIAAD, $\%+($ IEAA flow, g/kg DMI)/ (AA content of feedstuff, g/kg DM) x 100 .

\section{Chemical analysis}

The proximate compositions of the test ingredients, diets and digesta were determined by the methods of AOAC (2000). Amino acid analysis was determined by the method of Schroeder et al. (1990). Chromium concentrations in diets and digesta were determined spectrophotometrically after wet ash digestion with nitric and perchloric acids according to the method of Fenton and Fenton (1979).

\section{Statistical analysis}

Data were analysed using Descriptive statistics and ANOVA of SAS (SAS, 2012) and significant level of $\mathrm{P}=0.05$ was used. The treatment means were compared using Duncan's Multiple Range Test (Duncan, 1955).

\section{RESULTS AND DISCUSSION}

The apparent ileal digestibility of crude protein (CP) and amino acid (AA) in broiler finishers fed experimental diets is shown in Table 3. Birds fed maize-based diet had the least $\mathrm{CP}$ digestibility value $(68.17 \%)$ which was significantly $(\mathrm{P}<0.05)$ lower than that of birds fed wheat-based diet $(75.00 \%)$ and rice branbased diet $(79.08 \%)$ respectively. Crude protein digestibility value in birds fed soybean meal (SM) diet $(91.98 \%)$ and groundnut cake (GC) diet (90.07\%) were similar but higher than $\mathrm{CP}$ digestibility in other diets. It was observed that birds on GC diet had the highest AIAAD for all indispensable amino except histidine, leucine, lysine, methionine and valine. This highest digestibility values observed in birds fed GC diet can be attributed to the high protein content of groundnut cake in comparison to the other feed ingredients. According to Stein et al. (1999), low protein ingredients, like grains, can yield highly variable amino acid digestibilities, which is as a result of very low amino acid intake. Low protein and amino acid intakes may cause greater proportions of endogenous amino acids to be present in the digesta in relation to protein from dietary origin. When evaluating low protein assay diets, apparent amino acid digestibility will be underestimated due to high endogenous amino acid contribution. Woldroof (1985) reported that the digestibility of the protein of groundnut cake is very high, with a coefficient as high as $90 \%$. This report validates the result of this present study where CP digestibility of groundnut cake-based diet was observed to be $90.07 \%$ which was similar to that of birds fed on SM-based diet. However, Ravindran et al. (2005) reported a range of $75-85 \%$ for AID of $\mathrm{CP}$ and indispensable AA in broilers fed SM-based diet. This report contradicts the result of this present study for AID of CP for SM (91.98\%). The Ileal amino acid flow $(\mathrm{g} / \mathrm{kg})$ of birds fed nitrogen-free diet is presented in Table 4. Amino acids with the highest flow were threonine $(0.29 \pm 0.05)$, cysteine $(0.19 \pm 0.03)$, histidine $(0.17 \pm 0.03)$, lysine $(0.17 \pm 0.03)$, methionine $(0.10 \pm 0.01)$ and phenylalanine $(0.10 \pm 0.02)$ while the amino acids with the least flow were alanine $(0.03 \pm 0.01)$, glutamic acid $(0.03 \pm 0.01)$ and tyrosine $(0.04 \pm 0.01)$ respectively. However, the conspicuous ileal AA with the greatest flow was threonine. This result substantiates the report of Adedokun et al. (2007), Golian et al. (2008) and Iyayi and Adeola (2014), who reported that threonine and aspartic acid as the prominent amino acid in the ileal digesta of broiler chicken. According to Soleimani et al. (2010), the most abundant EIAAs flow in a non-heat stressed 42-d old broiler chickens were glutamic acid, followed by aspartic acid, serine and threonine. The high concentration of threonine in ileal digesta of birds observed in this study can be attributed to the contribution of mucin to ileal digesta. According to Lien et al. (1997), this may contribute to the low ileal apparent digestibility for threonine in many feedstuffs. 


\section{U. O. Olayemi et al.}

The range of endogenous amino acid flow observed in this study was lower than the range reported by Soleimani et al. (2010) in 42d old broiler chicken except for methionine, tryptophan and cysteine which were within the reported range. This disparity can be ascribed to the composition of the nitrogen-free diet used or several other factors that are known to affect endogenous amino acid losses such as mucin turnover rate, concentration of dietary protein or amino acid, dietary fiber, type of index marker, gut health etc.

Standardised ileal digestibility of crude protein and amino acid in broiler finishers fed experimental diets is shown in Table 5. There were significant $(\mathrm{P}<0.05)$ variations observed in the digestibility indices among dietary treatments. Similar CP digestibility was observed in SM diet (93.26\%) and GC diet (93.10\%). The CP digestibility values were significantly $(\mathrm{P}<0.05)$ higher than other dietary treatments (maize, wheat and rice bran). Apparent digestibility values that are corrected for only basal endogenous amino acid losses are considered to be standardised digestibilities (Lemme et al., 2004). Apparent ileal amino acid digestibility values of maize, wheat, soybean meal, groundnut cake and rice bran were corrected for basal endogenous amino acid losses to get the SIAAD values of these feedstuffs. Standardisation with mean values determined by NFD resulted in increased value of amino acid digestibility in the feedstuffs. After standardisation, birds fed on GC-based diet still maintained highest values for all indispensable amino acid except leucine, methionine and lysine which were highest in maize and rice bran based diets respectively. Among amino acids, threonine digestibility was most affected by the standardisation which is likely related to the high content of threonine in endogenous proteins. The result of this study compares favourably with the report of Urbaityte et al. (2009). The SIAAD values for soybean meal-based diet for all indispensable amino acid was within the range reported by Urbaityte et al. (2009) except for lysine, methionine and phenylalanine which were lower than the range of values reported. Furthermore, the range reported by Bernard (2000), for maize and wheat-based diets were higher than the range of values observed in this present study. This disparity can be attributed to the variety of the feedstuff or the composition of the nitrogen-free diet. The SIAAD values of most of the amino acids in wheat were lower compared to the other feed ingredients. This is probably due to the concentration of non-

starch polysaccharide (NSP) which could impair digestibility of amino acids. NSPs have been reported to reduce digestibility of several nutrients in poultry (Wiseman et al., 2000; Chesson, 2001). However, the SIAAD values observed in this study for birds fed on maizebased diet was in line with the SIAAD values reported by Iyayi and Adeola (2014). Isoleucine had the highest increase in wheat and GC with 3.1 and $3.73 \%$, respectively. In SM and maize, threonine had the lowest increase with 8.0 and $0.94 \%$, respectively. Average increase of SIAAD over AIAAD for indispensable amino acid was 1.58, 1.95, 1.37, 2.24 and $2.10 \%$ for maize, wheat, SM, GC and $\mathrm{RB}$ respectively. Increases in $\mathrm{GC}$ and $\mathrm{RB}$ diets were higher than increases in the maize, wheat and SM diets. Increment value reported in the present study for maize was lower than those of Iyayi and Adeola (2014).

\section{CONCLUSION}

Standardisation of AIAAD with endogenous amino acid losses values determined by the NFD method resulted in increased amino acid digestibility of all the selected feedstuffs. The SIAAD values of most of the amino acids in wheat were lower compared to the other feedstuffs. 
Poultry feedstuffs, Dietary amino acid, Endogenous nitrogen losses, Broiler finisher diets

\section{ACKNOWLEDGEMENTS}

The authors acknowledge the financial support given by Tertiary Education Trust
Fund (TETFund), Nigeria to carry out this study.

Table (1): Gross composition $(\mathrm{g} / \mathrm{kg})$ of experimental broiler chicken finisher diets

\begin{tabular}{|l|c|c|c|c|c|c|}
\hline Ingredients & NFD & Maize & Wheat & SM & GC & RB \\
\hline Maize & 0.00 & 960.50 & 0.00 & 0.00 & 0.00 & 0.00 \\
Wheat & 0.00 & 0.00 & 742.50 & 0.00 & 0.00 & 0.00 \\
Soybean meal & 0.00 & 0.00 & 0.00 & 464.50 & 0.00 & 0.00 \\
Groundnut cake & 0.00 & 0.00 & 0.00 & 0.00 & 472.50 & 0.00 \\
Rice bran & 0.00 & 0.00 & 0.00 & 0.00 & 0.00 & 400.50 \\
Corn starch & 271.50 & 0.00 & 0.00 & 226.00 & 0.00 & 0.00 \\
Dextrose & 579.00 & 0.00 & 198.00 & 250.00 & 468.00 & 540.00 \\
Soy oil & 50.00 & 0.00 & 20.00 & 20.00 & 20.00 & 20.00 \\
Cellulose & 60.00 & 0.00 & 0.00 & 0.00 & 0.00 & 0.00 \\
Limestone & 16.00 & 16.00 & 16.00 & 16.00 & 16.00 & 16.00 \\
Vitamin premix & 1.50 & 1.50 & 1.50 & 1.50 & 1.50 & 1.50 \\
Mineral premix & 1.00 & 1.00 & 1.00 & 1.00 & 1.00 & 1.00 \\
Table salt & 3.00 & 3.00 & 3.00 & 3.00 & 3.00 & 3.00 \\
Dicalcium phosphate & 18.00 & 18.00 & 18.00 & 18.00 & 18.00 & 18.00 \\
Total & 1000 & 1000 & 1000 & 1000 & 1000 & 1000 \\
\hline
\end{tabular}

$* \mathrm{NFD}=$ nitrogen free diet; $\mathrm{SM}=$ soyabean meal, $\mathrm{GC}=$ groundnut cake, $\mathrm{RB}=$ rice bran, ${ }^{*} *$ Composition of vitamin premix per kg of diet: vitamin A, 12,500 I.U; vitamin $\mathrm{D}_{3}, 2,500 \mathrm{I} . \mathrm{U}$; vitamin $\mathrm{E}$, $40 \mathrm{mg}$; vitamin $\mathrm{K}_{3}$, $2 \mathrm{mg}$; vitamin $\mathrm{B}_{1}, 3 \mathrm{mg}$; vitamin $\mathrm{B}_{2}, 5.5 \mathrm{mg}$; niacin, $55 \mathrm{mg}$; calcium pantothenate, $11.5 \mathrm{mg}$; vitamin $\mathrm{B}_{6}, 5 \mathrm{mg}$; vitamin $\mathrm{B}_{12}, 0.025 \mathrm{mg}$; choline chloride, $500 \mathrm{mg}$; folic acid, $1 \mathrm{mg}$; biotin; Composition of mineral premix per $\mathrm{kg}$ of diet:0.08mg; manganese, $120 \mathrm{mg}$; iron, $100 \mathrm{mg}$; zinc, $80 \mathrm{mg}$; copper, $8.5 \mathrm{mg}$; iodine, $1.5 \mathrm{mg}$; cobalt, $0.3 \mathrm{mg}$; selenium, $0.12 \mathrm{mg}$; Anti-oxidant, $120 \mathrm{mg}$.

Table (2): Calculated nutrients $(\mathrm{g} / \mathrm{kg})$ of experimental broiler chicken finisher diets

\begin{tabular}{|l|c|c|c|c|c|c|}
\hline Items & NFD & Maize & Wheat & SM & GC & RB \\
\hline Crude protein & 0 & 79.52 & 102.3 & 203.5 & 198.6 & 53.27 \\
Energy ME, kcal/kg & 3067 & 3212 & 2856 & 3124 & 2864 & 2994 \\
Fat & 0 & 35.6 & 18.15 & 83.7 & 34.5 & 52.13 \\
Crude fiber & 0 & 20.59 & 21.78 & 39.4 & 56.7 & 45.70 \\
Calcium & 9.86 & 10.05 & 10.22 & 11.4 & 10.6 & 10.14 \\
Total phosphorus & 3.24 & 5.9 & 5.9 & 6.3 & 5.8 & 9.30 \\
Non-phytate P & 4.40 & 4.60 & 4.60 & 4.70 & 4.60 & 4.80 \\
Lysine & 0 & 2.4 & 2.6 & 10.4 & 5.9 & 2.3 \\
Methionine & 0 & 1.7 & 1.5 & 2.5 & 2.1 & 1.0 \\
Threonine & 0 & 2.71 & 2.83 & 6.55 & 4.77 & 1.93 \\
Tryptophan & 0 & 0.56 & 1.16 & 2.37 & 1.85 & 0.48 \\
\hline
\end{tabular}

$\mathrm{NFD}=$ nitrogen free diet, $\mathrm{SM}=$ soybean meal, $\mathrm{GC}=$ groundnut cake, $\mathrm{RB}=$ rice bran 
Table (3): Apparent ileal digestibility (\%) of crude protein and amino acids in broiler finishers fed experimental diets

\begin{tabular}{|c|c|c|c|c|c|c|}
\hline AMINO ACID & MAIZE & WHEAT & SM & GC & $\mathbf{R B}$ & SEM \\
\hline $\mathrm{DM}$ & $75.81^{b}$ & $78.14^{\mathrm{b}}$ & $79.27^{\mathrm{a}}$ & $74.20^{\mathrm{d}}$ & $79.12^{\mathrm{a}}$ & 0.15 \\
\hline $\mathrm{CP}$ & $68.17^{\mathrm{d}}$ & $75.00^{\mathrm{c}}$ & $91.98^{\mathrm{a}}$ & $90.07^{\mathrm{a}}$ & $79.08^{\mathrm{b}}$ & 1.57 \\
\hline \multicolumn{7}{|c|}{ Indispensable amino acids } \\
\hline Histidine & $93.67^{b}$ & $85.32^{\mathrm{d}}$ & $94.37^{\mathrm{a}}$ & $93.82^{\mathrm{b}}$ & $89.93^{\mathrm{c}}$ & 0.31 \\
\hline Isoleucine & $88.38^{\mathrm{a}}$ & $70.25^{\mathrm{c}}$ & $78.83^{\mathrm{b}}$ & $89.50^{\mathrm{a}}$ & $39.24^{\mathrm{d}}$ & 1.27 \\
\hline Leucine & $92.09^{\mathrm{a}}$ & $74.18^{\mathrm{d}}$ & $81.29^{c}$ & $89.43^{\mathrm{b}}$ & $79.85^{\mathrm{c}}$ & 1.44 \\
\hline Lysine & $56.17^{\mathrm{d}}$ & $53.66^{\mathrm{e}}$ & $75.62^{b}$ & $72.38^{\mathrm{c}}$ & $88.71^{\mathrm{a}}$ & 0.89 \\
\hline Methionine & $85.28^{\mathrm{a}}$ & $55.09^{\mathrm{d}}$ & $74.46^{\mathrm{c}}$ & $81.45^{\mathrm{b}}$ & $51.95^{\mathrm{e}}$ & 1.73 \\
\hline Phenylalanine & $82.43^{\mathrm{b}}$ & $68.03^{\mathrm{d}}$ & $71.38^{\mathrm{c}}$ & $86.43^{\mathrm{a}}$ & $24.89^{\mathrm{e}}$ & 1.26 \\
\hline Threonine & $89.08^{\mathrm{b}}$ & $77.67^{d}$ & $86.71^{\mathrm{c}}$ & $91.53^{\mathrm{a}}$ & $69.62^{\mathrm{e}}$ & 0.98 \\
\hline Tryptophan & $85.24^{\mathrm{b}}$ & $72.74^{\mathrm{d}}$ & $79.22^{c}$ & $89.19^{\mathrm{a}}$ & $64.98^{\mathrm{e}}$ & 1.33 \\
\hline Valine & $64.49^{\mathrm{d}}$ & $55.23^{\mathrm{e}}$ & $73.45^{\mathrm{c}}$ & $81.56^{\mathrm{b}}$ & $93.23^{\mathrm{a}}$ & 1.35 \\
\hline \multicolumn{7}{|c|}{ Dispensable amino acids } \\
\hline Alanine & $68.84^{\mathrm{d}}$ & $63.63^{\mathrm{e}}$ & $89.63^{b}$ & $91.37^{\mathrm{a}}$ & $79.41^{\mathrm{c}}$ & 0.96 \\
\hline Asparagine & $98.06^{\mathrm{a}}$ & $97.66^{\mathrm{b}}$ & $97.80^{\mathrm{b}}$ & $90.14^{\mathrm{c}}$ & $97.72^{\mathrm{e}}$ & 0.13 \\
\hline Aspartic acid & $81.86^{\mathrm{a}}$ & $68.51^{\mathrm{c}}$ & $80.28^{\mathrm{a}}$ & $31.69^{d}$ & $73.06^{\mathrm{b}}$ & 1.51 \\
\hline Cysteine & $96.18^{\mathrm{a}}$ & $67.34^{\mathrm{e}}$ & $88.57^{\mathrm{c}}$ & $92.87^{\mathrm{b}}$ & $72.91^{\mathrm{d}}$ & 0.93 \\
\hline Glutamic acid & $66.54^{\mathrm{d}}$ & $63.05^{\mathrm{e}}$ & $85.17^{\mathrm{b}}$ & $89.51^{\mathrm{a}}$ & $70.44^{\mathrm{c}}$ & 0.87 \\
\hline Glycine & $50.99^{c}$ & $42.39^{\mathrm{d}}$ & $67.65^{\mathrm{b}}$ & $42.45^{\mathrm{d}}$ & $72.79^{a}$ & 1.98 \\
\hline Proline & $45.73^{\mathrm{e}}$ & $55.84^{\mathrm{c}}$ & $47.38^{\mathrm{d}}$ & $77.29^{\mathrm{a}}$ & $64.14^{\mathrm{b}}$ & 1.50 \\
\hline Serine & $63.02^{\mathrm{c}}$ & $56.17^{\mathrm{d}}$ & $62.59^{c}$ & $81.86^{\mathrm{a}}$ & $65.82^{\mathrm{b}}$ & 1.65 \\
\hline Tyrosine & $81.41^{\mathrm{b}}$ & $63.19^{d}$ & $73.15^{\mathrm{c}}$ & $88.22^{\mathrm{a}}$ & $45.61^{\mathrm{e}}$ & 1.18 \\
\hline TAA & $69.47^{\mathrm{c}}$ & $59.49^{\mathrm{e}}$ & $70.48^{b}$ & $73.04^{\mathrm{a}}$ & $62.21^{\mathrm{d}}$ & 0.68 \\
\hline
\end{tabular}

abcde Means with the same superscripts are not significantly different $(\mathrm{P}>0.05)$. SEM=standard error mean; $\mathrm{SM}=$ soybean meal; $\mathrm{GC}=$ groundnut cake; $\mathrm{RB}=$ rice bran; $\mathrm{AA}=$ amino acid; $\mathrm{DM}=$ dry matter; $\mathrm{CP}=$ crude protein; TAA =total amino acids 
Table (4): Ileal endogenous amino acid flow ( $\mathrm{g} / \mathrm{kg}$ DM intake) of birds fed nitrogen-free diet

\begin{tabular}{|l|c|}
\hline AMINO ACID & ILEA L FLOW \\
\hline Indispensable amino acids & $0.17 \pm 0.03$ \\
\hline Histidine & $0.07 \pm 0.02$ \\
Isoleucine & $0.09 \pm 0.02$ \\
Leucine & $0.17 \pm 0.03$ \\
Lysine & $0.10 \pm 0.01$ \\
Methionine & $0.10 \pm 0.02$ \\
Phenylalanine & $0.29 \pm 0.05$ \\
Threonine & $0.07 \pm 0.01$ \\
Tryptophan & $0.07 \pm 0.01$ \\
Valine & \\
\hline Dispensable amino acids & $0.03 \pm 0.01$ \\
\hline Alanine & $0.06 \pm 0.02$ \\
Asparagine & $0.07 \pm 0.01$ \\
Aspartic acid & $0.07 \pm 0.01$ \\
Serine & $0.19 \pm 0.03$ \\
Cysteine & $0.03 \pm 0.01$ \\
Glutamic acid & $0.07 \pm 0.02$ \\
Glycine & $0.07 \pm 0.02$ \\
Proline & $0.07 \pm 0.01$ \\
Serine & $0.04 \pm 0.01$ \\
Tyrosine & \\
\hline
\end{tabular}

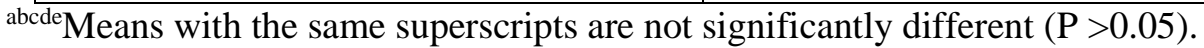


U. O. Olayemi et al.

Table (5): Standardised Ileal digestibility (\%) of crude protein and amino acid in broiler chicken finisher fed experimental diets

\begin{tabular}{|c|c|c|c|c|c|c|}
\hline AA/DIETS & MAIZE & WHEAT & SM & GC & RB & SEM \\
\hline $\mathrm{CP}$ & $69.84^{\mathrm{d}}$ & $77.27^{\mathrm{c}}$ & $93.26^{\mathrm{a}}$ & $93.10^{\mathrm{a}}$ & $82.11^{\mathrm{b}}$ & 1.57 \\
\hline \multicolumn{7}{|c|}{ Indispensable amino acids } \\
\hline Histidine & $95.86^{\mathrm{c}}$ & $87.59^{d}$ & $95.65^{\mathrm{c}}$ & $96.85^{\mathrm{a}}$ & $92.96^{\mathrm{b}}$ & 0.31 \\
\hline Isoleucine & $90.34^{\mathrm{b}}$ & $73.35^{\mathrm{d}}$ & $81.49^{c}$ & $93.23^{\mathrm{a}}$ & $41.11^{\mathrm{e}}$ & 1.27 \\
\hline Leucine & $93.39^{\mathrm{a}}$ & $75.69^{d}$ & $82.89^{c}$ & $91.52^{\mathrm{b}}$ & $81.66^{\mathrm{c}}$ & 1.44 \\
\hline Lysine & $58.40^{\mathrm{d}}$ & $56.06^{\mathrm{e}}$ & $76.88^{c}$ & $74.85^{\mathrm{b}}$ & $91.55^{\mathrm{a}}$ & 0.89 \\
\hline Methionine & $86.69^{\mathrm{a}}$ & $57.10^{\mathrm{d}}$ & $75.87^{\mathrm{c}}$ & $83.63^{b}$ & $54.48^{\mathrm{e}}$ & 1.73 \\
\hline Phenylalanine & $83.77^{\mathrm{b}}$ & $69.41^{\mathrm{d}}$ & $72.76^{\mathrm{c}}$ & $88.32^{\mathrm{a}}$ & $27.05^{\mathrm{e}}$ & 1.26 \\
\hline Threonine & $90.02^{\mathrm{b}}$ & $78.76^{\mathrm{d}}$ & $87.51^{\mathrm{c}}$ & $92.88^{\mathrm{a}}$ & $70.98^{e}$ & 0.98 \\
\hline Tryptophan & $86.48^{\mathrm{b}}$ & $74.67^{\mathrm{d}}$ & $80.19^{c}$ & $91.00^{\mathrm{a}}$ & $66.69^{\mathrm{e}}$ & 1.13 \\
\hline Valine & $66.06^{\mathrm{d}}$ & $57.13^{\mathrm{e}}$ & $74.46^{\mathrm{c}}$ & $83.13^{b}$ & $94.84^{\mathrm{a}}$ & 1.35 \\
\hline \multicolumn{7}{|c|}{ Dispensable amino acids } \\
\hline Alanine & $70.27^{d}$ & $66.74^{\mathrm{e}}$ & $92.75^{b}$ & $96.04^{\mathrm{a}}$ & $80.65^{\mathrm{c}}$ & 0.95 \\
\hline Asparagine & $99.27^{\mathrm{a}}$ & $99.22^{\mathrm{a}}$ & $98.53^{\mathrm{c}}$ & $90.58^{d}$ & $98.87^{\mathrm{b}}$ & 0.13 \\
\hline Aspartic acid & $82.96^{\mathrm{a}}$ & $69.79^{d}$ & $81.11^{\mathrm{b}}$ & $34.17^{\mathrm{e}}$ & $74.53^{\mathrm{c}}$ & 1.15 \\
\hline Cysteine & $97.49^{\mathrm{a}}$ & $69.19^{\mathrm{e}}$ & $90.59^{c}$ & $95.35^{\mathrm{b}}$ & $74.63^{d}$ & 0.93 \\
\hline Glutamic acid & $68.02^{\mathrm{b}}$ & $65.79^{\mathrm{e}}$ & $87.05^{\mathrm{b}}$ & $92.48^{\mathrm{a}}$ & $72.67^{\mathrm{c}}$ & 0.87 \\
\hline Glycine & $51.90^{\mathrm{c}}$ & $43.85^{\mathrm{d}}$ & $68.55^{\mathrm{b}}$ & $43.85^{\mathrm{d}}$ & $74.37^{\mathrm{a}}$ & 1.97 \\
\hline Proline & $48.52^{\mathrm{d}}$ & $59.09^{c}$ & $49.28^{\mathrm{d}}$ & $80.86^{\mathrm{a}}$ & $68.47^{b}$ & 1.49 \\
\hline Serine & $64.46^{\mathrm{c}}$ & $57.86^{\mathrm{d}}$ & $63.61^{\mathrm{c}}$ & $83.79^{\mathrm{a}}$ & $67.92^{\mathrm{b}}$ & 1.65 \\
\hline Tyrosine & $83.41^{\mathrm{b}}$ & $64.95^{\mathrm{d}}$ & $76.10^{\mathrm{c}}$ & $90.13^{\mathrm{a}}$ & $47.52^{\mathrm{e}}$ & 1.18 \\
\hline TAA & $70.86^{\mathrm{c}}$ & $61.30^{\mathrm{d}}$ & $71.76^{b}$ & $75.13^{\mathrm{a}}$ & $64.05^{\mathrm{c}}$ & 0.67 \\
\hline
\end{tabular}

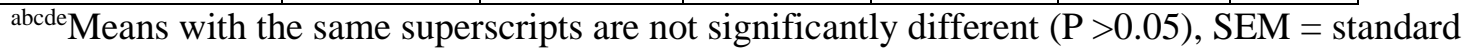
error mean; $\mathrm{SM}=$ soybean meal; $\mathrm{GC}=$ groundnut cake; $\mathrm{RB}=$ rice bran; $\mathrm{AA}=$ amino acid $\mathrm{CP}=$ crude protein; TAA =total amino acids 


\section{REFERENCES}

Adedokun, S. A.; Parsons, C. M.; Lilburn, M. S.; Adeola, O.; and Applegate, T. J. 2007. Endogenous amino acid flow in broiler chicks is affected by the age of birds and method of estimation. Poult. Sci., 86:2590-2597.

Adedokun, S. A.; Adeola, O.; Parsons, C. M.; Lilburn, M. S.; and Applegate, T. J. 2008. Standardized ileal amino acid digestibility of plant feedstuffs in broiler chickens and turkey poults using a nitrogen-free or casein diet. Poult. Sci., 87: 2535-2548.

AOAC 2000. Official Method of Analysis, 15th Edn. Association of official analytical chemists, Washington DC.

Bernard, H. R.; 2000. Social research methods: qualitative and quantitative approaches. Thousand oaks, CA: Sage.

Chesson, A.; 2001. Non-starch polysaccharide degrading enzymes in poultry diets: Influence of ingredient on the selection activities. World's Poult. Sci. J. 57: 251-262.

Duncan, D. B. 1955. Multiple range and multiple F-Test. Biometrics, 11, 1-5.

Fan, M. Z.; Sauer, W. C.; Hardin, R. T.; and Lien, K. A. 1994. Determination of apparent ileal amino acid digestibility in pigs: Effect of dietary amino acid level. J. Anim. Sci., 72:2851-2859.

Fenton, T. W.; and Fenton, M. 1979. An improved procedure for the determination of dietary chromic oxide in feed and feces. Can. J. Anim. Sci., 59:631-634.

Golian, A.; Guenter, W.; Hoehler, D.; Jahanian, H.; and Nyachoti, C. M. 2008. Comparison of various methods for endogenous ileal amino acid flow determination in broiler chickens. Poult. Sci., 87:706-712.

Iyayi, E. A.; and Adeola, O. 2014. Standardized ileal amino acid digestibility of feedstuffs in broiler chickens. Eur. Poult. Sci., 78:1-12. Lemme, A.; Ravindran, V.; and Bryden, W. L. 2004. Ileal digestibility of amino acid in feed ingredients for broilers. World's Poult. Sci., 60:423-437.

Lien, K. A.; Sauer, W. A.; and Fenton, M. 1997. Mucin output in ileal digesta of pigs fed a protein-free diet. Z. Ernährungswiss. 36:182-190.

Ravindran, L.; Hew, L. I.; Ravindran, G.; and Bryden, W. L. 2005. Apparent ileal digestibility of amino acids in dietary ingredients for broiler chickens. Anim. Sci., 81(1): 85-97.

Rostagno, H. S.; Pupa, J. M. R.; and Pack, M. 1995. Diet formulation for broilers based on total versus digestible amino acids. J. of Appl. Poult. Res., 4: 293-299.

SAS Institute Inc. 2012. SAS/STAT. User's Guide. Version 8 for windows. SAS Institute Inc., Cary North Caroline, USA.

Schroeder, W.A.; Kay, L. M.; and Mills, R.S. 1990. Spectrophotometric analysis of amino acids using ninhydrin chemical reaction. Anal. Chem., 22: 760-760.

Soleimani, A. F.; Kasim, A.; Alimon, A. R.; Meimandipour, A.; and Zulkifli I. 2010. Ileal endogenous amino acid flow of broiler chickens under high ambient temperature. J. Anim. Physiol. Anim. Nutr., 94(5):641-7.

Stein, H. H.; Trottier, N. L.; Bellaver, C.; and Easter, R. A. 1999. The effects of feeding level and physiological status on total flow and AA composition of endogenous protein at the distal ileum in swine. J. Anim. Sci., 77: 1180-1187.

Urbaityte, R.; Mosenthin, R.; Eklund, M.; Piepho, H. P.; and Rademacher, M. 2009. Determination of standardized ileal crude protein and amino acid digestibilities in protein supplements for piglets. Animal, 3(12): 1696-1705.

Wiseman, J.; Nicol, N. T.; and Norton, G. 2000. Relationship between apparent metabolisable (AME) values and in vivo/in vitro starch digestibility of wheat for broilers. World's Poult. Sci. J. 56: 306-318. 
U. O. Olayemi et al.

Woldroof, W.D. 1985. Soybean for poultry

feeds. Animal Nutrition Research, 46:

161 